\title{
Article
}

\section{Rethinking Vocational Rehabilitation through Institutional Ethnography}

by

Siri Yde Aksnes

PhD student

Faculty of Social Sciences

Oslo and Akershus University College of Applied Sciences

P.O. Box 4 St. Olavs plass, 0130 Oslo, Norway

+4767238388

Siri-Yde.Aksnes@hioa.no

\section{Keywords:}

institutional ethnography, vocational rehabilitation, implementation research, activation policy, Norway

\section{(c) (D) (D)}

This work is licensed under a Creative Commons Attribution-ShareAlike 4.0 International License. 
Abstract: In Norway, vocational rehabilitation for people with support needs involves complex inter-professional and inter-organizational processes that do not have clear institutional boundaries. Every process involves a new constellation of actors, representing divergent practices, ideas and objectives. This article argues that much of the current research on the implementation of activation policy inadequately captures the mechanisms and processes that influence vocational rehabilitation practices. The article proposes the use of institutional ethnography (IE) to empirically examine vocational rehabilitation, and argues that IE provides methodological concepts and tools that enable researchers to link and make visible the everyday practices, the social relations and the institutional contexts that make up vocational rehabilitation processes.

\section{Keywords:}

institutional ethnography, vocational rehabilitation, implementation research, activation policy, Norway 


\section{Introduction}

This article examines the possibility of analysing processes of vocational rehabilitation through institutional ethnography (IE). The article examines how IE can contribute to a more nuanced and holistic picture of the intricate interactions occurring in vocational rehabilitation. IE offers researchers a number of conceptual tools to connect people's experiences and practices in institutional processes with larger social relations occurring elsewhere. The research approach thereby calls on the researcher to look at the world in a certain way' (Rankin \& Campbell, 2006, p. 186).

My interest in vocational rehabilitation grew out of my work as a counsellor in a vocational rehabilitation enterprise. I started working as a counsellor in 2012, after I finished my master's degree in social anthropology. The transition between student life and working life was big, especially because I now had to deal with a profoundly challenging undertaking, namely assisting persons with support needs to participate in the labour market. The people I worked with - my 'clients' - were individuals struggling with mental illnesses, psychosomatic or psychosocial problems and disabilities. In addition to being able to assess their work capability and support them toward employment, I was also supposed to possess solid knowledge about the labour market. I remember being referred to as a 'job specialist', something I found rather uncomfortable, as I was not sure what that meant.

As I began to learn more about how my work was organized, a number of disjunctures emerged, which my anthropological background led me to question and want to better understand. The most troubling disjuncture was that no matter how 'empowered' and motivated for work my clients became, many of them were still not able to acquire work, mainly because of structural factors in the labour market. The opportunities for entering the labour market are low for people with a reduced work capability, especially if they have poor language skills and lack education as well. A second disjuncture was that even though the vocational rehabilitation programme was framed by relatively strict regulations, my role as a counsellor was highly flexible and discretionary. Another was that although the work seemed quite focused on assisting a person to get a job on the surface, in actuality my job required me to take on a range of tasks. In each individual process, I engaged with a number of other professionals and often had to consider a 
wealth of health-related and social barriers on the client's pathway to employment. Lastly, although our mandate was clear - to support persons toward gaining employment- the discussions between the people involved about how to achieve this were not. Instead of being straightforward and concrete, the conversations were filled with vague, normative, institutional terms like 'client participation' and 'tailor-made services', which I had to translate and fill with meaning myself. As time went by, I became skilled at doing 'counselling work' and (more or less) adapted to the taken-forgranted institutional understandings and practices surrounding the field of vocational rehabilitation. However, the incongruities I experienced at work inspired me to want to examine the field ethnographically, to 'unpack' what was really going on. After discovering IE, I was taken by its potential to render visible the links between ethnographically accessible everyday practices and the larger institutional practices, policies and discourses that frame them. Moreover, IE offers tools to investigate how dominant institutional relations in vocational rehabilitation are actually played out in the practices of individuals. I was also surprised to learn that IE did not seem to have been used to analyse processes of vocational rehabilitation.

IE is a theoretically informed research approach (Bisaillon, 2012, p. 614) and an alternative sociology (Smith, 2005). In this article, however, the focus is primarily on the various methodological techniques and strategies within IE, and on what they offer to the study of vocational rehabilitation services. The aim is to explore the possibilities for rethinking the field of vocational rehabilitation through IE, to contribute to a methodological discussion on vocational rehabilitation and to inspire future IE research within this field.

The article first reviews the main contributions to implementation studies of active labour market programmes, and points to why these inaccurately capture how vocational rehabilitation and training for persons with support needs actually takes place. From here, I move into a discussion about what new insights IE can add to the study of vocational rehabilitation. For this purpose, I have relied on examples from a case study in Norway. Finally, the article concludes by identifying future opportunities for IE-inspired research on vocational rehabilitation. 


\section{From Policy to Action: Studies on Implementation}

Vocational rehabilitation services and other interventions aimed at getting unemployed people off benefits and into work are collectively referred to as active labour market policies (ALMPs) or activation policies (e.g. Greve, 2014). Here, I refer to vocational rehabilitation as an ALMP aimed at persons considered to need long-lasting help and assistance. A considerable amount of literature from disciplines such as economics, political science, sociology and social work investigates ALMPs and their outcomes. Because the various disciplines approach the issues of activation policies from different angles, activation research has become a subfield of a mixture of disciplines.

Of particular relevance for this article are empirical studies examining the implementation of activation policies. One strand of this literature has examined how the practices of street-level bureaucrats have affected the implementation of official activation and rehabilitation policies (Van Berkel \& Knies, 2016; Brodkin \& Marston, 2013; Thorén, 2008; Hupe \& Hill, 2007; Meyers \& Vorsanger, 2003). Other scholars have analysed the organization and implementation of activation services from the perspective of the beneficiaries of the services (Dubois, 2010; Anker \& Halvorsen, 2007; Mäkitalo, 2006; Järvinen \& Mik-Meyer, 2003; Helgøy, 1998). Others have examined the interaction between service providers and beneficiaries (Lundberg, 2012). More recently, scholars have focused on the experiences and responses of employers to activation policies (Ingold \& Stuart, 2015; Van der Aa \& Van Berkel, 2014; Martin, 2004). Theoretically, much of the literature on the implementation of activation policies has been informed by Lipsky's theory of street-level bureaucracies and theories of symbolic interactionism. Below, I briefly outline the two perspectives.

Lipsky (1980) described the daily work of street-level bureaucrats (public service workers) in great detail, focusing on their vast caseloads, few resources and conflicting objectives. To overcome the complexity and often contradictory purposes in their work, street-level staff have developed coping techniques, of which the most prominent is reducing the people they are supposed to help to being 'clients' or 'cases'. Lipsky's main argument was that street-level bureaucrats are the real policymakers (1980, p. 13), and make a huge impact on policy outcomes. This is primarily due to street-level bureaucrats' relative autonomy from public authorities, as well as their extensive use 
of discretion. Since 1980, a large body of research has refined and augmented Lipsky's theory of street-level bureaucracy. Hill and Hupe combined Lipsky's insights with perspectives aimed at capturing 'the micro-network of relations' (2007, p. 279) in streetlevel work. Other scholars, such as Thorén (2008), have addressed how politicalinstitutional context and organizational factors impact street-level practice (2008, p. 16). In her Swedish study, Thorén wanted to amend the literature on street-level implementation to be better suited to institutional contexts in other countries (Thorén, 2008, p. 17).

A second dominant perspective in implementation research is symbolic interactionism. The perspective refers to several theories that are all based on the ontological assumption that meaning is produced through the interactions of individuals in microsociological situations (e.g. Blumer, 1969; Aakvaag, 2008). Goffman's (1959) dramaturgical model of human beings, and his metaphors from theatre, has been a key approach used in symbolic interactionism. Symbolic interactionism is considered to provide an ideal conceptual framework for social work theorizing and practice because of its extensive attention to communication, meaning and social roles (e.g. Forte, 2004; Horner, 1979). A central assumption within this perspective is that institutional encounters are characterized by negotiation and 'impression management' (Goffman, 1959). Both clients and professionals develop strategies and roles toward each other, and in relation to the institutional setting they are part of (e.g. Mäkitalo, 2006; Dubois, 2010).

Since Lipsky (1980), scholars on activation policies tend to agree that institutional discourses and current social policies do not influence the actors' practices in a oneway direction, but are negotiated and put into play in ways other than originally intended. Studying the large issue of policy implementation in small places like public agencies has become a widespread approach in empirical studies on implementation processes, which is a reliable methodological starting point. Nevertheless, Lipskyinspired research and research drawing on symbolic interactionism both have a weak point in their insufficient attempts to show how local practices integrate and connect with larger political and institutional discourses. This shortcoming is especially unfortunate in the study of the complex, institutional landscape of activation policies. In vocational rehabilitation processes interactions are heavily institutionalized, and I 
would argue, cannot be sufficiently understood without involving the institutional context. Although many scholars have paid attention to the political and organizational paradoxes characterizing street-level practices, few of them have managed to unveil how these paradoxes come into play. This article argues that IE offers a methodological position in which the different analytical levels and empirical contexts that constitute vocational rehabilitation can be linked and integrated.

\section{Institutional Ethnography as Methodological Framework}

In creating IE as a method of inquiry, the Canadian sociologist Dorothy Smith's (2005) central concern was how people's everyday lives are socially organized. Starting within the immediate surroundings of people's lives when inquiring about their practices and social experiences, Smith has investigated 'how activities are socially coordinated' (2005, p. 57). Smith's main purpose has been to create an alternative, anti-objectifying sociology for and with people (2005). Over the last 30 years, IE has gained an established position within the social sciences.

Gaining an understanding of the social world as produced by people's practices involves rejecting the abstract and conceptual way of knowing about things (Bisaillon, 2012). When treating people as active subjects with a thorough knowledge of their everyday life, institutional ethnographers are 'transferring agency away from concepts... back to the embodied knower' (Deveau, 2008, p. 5). This 'ontological shift' (Smith, 1990, p. 633) also implies a shift in approach from aiming to explain 'why things happen the way they do to how things happen the way they do' (Deveau, 2008, p. 6 my emphasis). In line with this, I argue that research on vocational rehabilitation can benefit from a greater attention to how inclusion is actually accomplished and coordinated at specific workplaces. By exploring 'how things work', difficult concepts such as inclusion and tailoring can be given content and meaning.

In IE, describing a local setting such as a job training process at a workplace is not an end in itself. Rather, individual descriptions become a key to discovering how the local actions of people are connected to- and organized by larger institutional processes that happen elsewhere (Rankin \& Campbell, 2006, pp. 186-188). The connections between people's everyday practices and so-called ruling relations are essential in 
institutional ethnographers' investigations of how things work. Ruling relations are complex social relations that constitute and coordinate people's actions across time and space, often without their conscious knowledge (Campbell \& Gregor 2008, p. 31). To discover ruling relations, it is essential to investigate texts, because in modern societies ruling is often made possible in textually mediated form. Texts can create standardized concepts and objectified forms of knowledge (Widerberg, 2015) through their fixed and reproducing character (DeVault \& McCoy, 2006, p. 765). However, ruling is not only present in a material form, but also takes the shape of more broadly defined institutional discourses, and is present in the language people use, the way they write and use texts, and in how they organize their work. Within activation studies, policy documents, legislation, professional language, Individual Plans, reports and contracts are examples of texts and discourses that shape and govern the actions of

The starting point in an institutional ethnography is always people's everyday practices, and not the discourses that they participate in. Thus, IE research has a defined methodological direction. The researcher investigates from the standpoint of a person in an institutional setting, for example, a counsellor in a vocational rehabilitation enterprise, and examines this person's knowledge of- and experience with their practices, as well as the coordination of their work with the work of others (Smith, 2005). People's work knowledge ${ }^{1}$ becomes the IE researcher's primary resource, and the methodological emphasis on standpoint and work knowledge grounds the research in a particular perspective. To explore and render visible how people's actions are coordinated, the IE researcher maps out the social relations framing the chosen standpoint, with each map providing a partial view of the settings under scrutiny. The mapping of the relations between a client, a counsellor and a potential employer might reveal differences, or even dissonances, between their understandings, work practices and experiences in the institutional setting under investigation. Despite the analytic challenges posed by putting these accounts together, the ongoing process of mapping can provide insights into how vocational rehabilitation is organized and negotiated.

Smith describes IE as a 'method of inquiry' (2005, p. 1) and the everyday world as an unfinished arena of discovery (2005, p. 39). The research field must be kept open for investigation in the sense that nothing must be taken for granted. In this respect, knowing the field of vocational rehabilitation, as I did, was not an advantage. However, 
IE offers, several other tools that can help researchers who know a field to achieve openness. One of them is to avoid 'closing' the field early in the process through a conceptualization in the form of a research question. The researcher must discover and identify a problematic as the research process develops (Campbell \& Gregor, 2008 , p. 47). A problematic refers to a set of possible questions implicit in the organization of the field. The process develops into an inquiry when the researcher starts questioning how things are organized (Grahame, 1998, p. 350). After formulating it, the researcher keeps the problematic as a guideline throughout the different sites of research.

Like other qualitative researchers, the institutional ethnographer may rely on observational methods, interviews and textual data; yet what the researcher 'looks and listens for" is more IE specific. The analytic process of IE research starts during data collection. The researcher gradually makes sense of the empirical findings, using the above-mentioned concepts and tools. IE implies an explorative and flexible research design of developing the problematic in response to findings, following informants' knowledge and beliefs, and continually checking one's own understanding. In my case, this ongoing, reflexive process of trying to grasp 'what is at stake' for the informants would help me to correct any possible biases and preconceptions I had from my work as a counsellor.

In the end, the IE researcher is able to develop a conceptualization based on actual social processes. This is possible because, as Campbell and Gregor (2008, p. 86) point out, 'a successful analysis supersedes any one account, and even supersedes the totality of what informants know and can tell'. In other words, the analysis has more to it than simply collecting and interpreting different informants' accounts. Institutional ethnographers aim at explicating everyday experiences (Campbell \& Gregor, 2008, p. 90) through investigating how context shapes practice (Townsend, 1996).

In our efforts to create new and improved maps of social settings, we researchers must not downplay the importance of an ongoing reflexivity in terms of what we make visible and leave invisible in our research. Reflexivity is needed because, as Walby (2007) argues, institutional ethnographers also create objectified versions of truth, 
emphasizing some questions while disregarding others, interpreting and writing up their findings according to the IE discourse. There are 'degrees of objectification', however, and the aim for all qualitative researchers must be to minimize objectification (Walby, 2007, p. 1010). Although IE has the potential to create research that resonates with the experiences of people under study, this is not necessarily a straightforward achievement. Among other things, it requires that researchers recognize and reflect upon their own participation in a specific scientific discourse.

\section{Setting the Scene: Vocational Rehabilitation in Norway}

Since the 1990s, social policymakers in Europe have initiated a significant number of reform processes, putting forth a paradigm shift in the functioning of public institutions (Van Berkel, 2007, p. 259). Van Berkel and Valkenburg (2007, pp. 7-14) point to three parallel and interconnected transformation processes in social policies that have influenced activation policies. These are shifts from the so-called 'passive' toward 'active' welfare states, from 'traditional state responsibilities and authorities' toward 'new modes of governance' and from a 'one-size-fits-all approach' toward an 'individualization of service provision'. Yet, according to Newman (2007), the institutional changes in activation policies do not constitute a general trend or one integrated reform. It's actually quite the opposite; the changes are partly incoherent because the different discourses of welfare are entangled in different discourses of governance (Newman, 2007, p. 365), leading to tensions and ambivalence within welfare states. One such potential source of tension, which is tracked down in this article, is the dynamic between the increased emphasis on accountability and efficiency in terms of labour market entry on the one side, and considering the clients' everyday lives and struggles on the other.

In Norway, the reform policies of workfare and activation from the 1990s are strategically and ideologically reflected in a comprehensive work and welfare sector. The ALMPs are administrated by the Norwegian Labour and Welfare Administration (NAV), which purchases services from a wide range of vocational rehabilitation enterprises. Despite huge efforts, Norway has not performed particularly well in promoting labour market participation of people with health problems (Heggebø, 2016; Halvorsen \& Hvinden, 2011). Insufficient results have led to increased attention from the authorities' side to how public spending related to ALMP programmes are used, 
and to considerable reform processes in Norwegian activation policies over the past decades (e.g. Andreassen \& Fossestøl, 2014). Strategies associated with the probusiness ideology of New Public Management (NPM), such as contracting, performance measurements, documentation requirements and reporting systems, characterize some of these reform processes (e.g. Lundberg, 2012; Kasin \& Sannes, 2012). NPM strategies have led to new demands on vocational rehabilitation enterprises, increased pressure to produce results (in terms of labour market entry for the target groups) and competition between providers of vocational rehabilitation services (Kasin \& Sannes, 2012). In 2014, the largest ALMP programmes in Norway were tendered in order to increase the quality of the programmes and the plurality of service provision (PROBA, 2016).

Another considerable change in Norwegian activation policy concerns the traditional understanding of the relationship between health and work (e.g. Andreassen \& Fossestøl, 2014). To an increasing extent, Norwegian authorities assert that people can, and even should, work despite their health problems (White Paper no. 9 (20062007). This 'employability-enhancing' approach has contributed to blurring the lines between healthy/employable and sick/unemployable (Andreassen \& Fossestøl, 2014).

Considering the diversities of discourses underlying current ALMPs, we need research that enables us to explore and open up the intricate relations between systemic changes and practice in vocational rehabilitation. In the local interactions between counsellors and clients in vocational rehabilitation processes, ambiguities and paradoxes are translated, negotiated and put into action.

\section{Study Design}

This article forms part of a larger study about the relationship between employers and vocational rehabilitation staff in an employer-initiated recruitment project. Over a period of 1.5 years, I conducted 24 interviews with central actors within this project, and participated in 15 formal meetings at different levels, as well as a number of seminars, events and informal settings. For this article, I analyse interviews with two female counsellors, Mari and Charlotte, working in two different vocational rehabilitation programmes. I chose these two 'cases' because their stories represent a general 
finding in the data of how counselling work is entangled among particular institutional discourses on how to do vocational rehabilitation. Moreover, the examples can shed light on my own experience of incongruities in my previous job as a counsellor.

I first met Mari and Charlotte at two different seminars I attended. After having had lunch with each of them, I was invited to their workplace. On my first visits, we had long and relatively open talks about their daily work tasks and their thoughts and reflections on their work. The aim was to find out what was important for them in their daily activities. I met them again after some months. This time I had conceptualized the problematic that would guide my inquiry, and planned for semi-structured interviews with more detailed and targeted questions. Additionally, I met Mari and Charlotte at meetings, seminars and events several times during the course of my data collection. I recorded the talks/interviews, and for the purposes of this article, the data sources include four talks/interviews that ranged from 45 minutes to three hours.

IE researchers DeVault and McCoy (2006, p. 20) suggest following a three-step sequence in an IE analysis: First, identify an experience that appears puzzling, and make it the problematic. Second, identify some of the institutional processes shaping that specific experience. Third, investigate how those processes 'operate as the grounds of the experience' identified in the first step. These analytical steps can be seen as representing different analytical levels, from the micro to the macro. However, to distinguish between analytical

levels is not a straightforward task because individuals' experiences and institutional processes are not self-sufficient phenomena, but instead deeply intertwined with one another (Grahame, 1998, p. 356). Accordingly, in my analysis the analytical levels are not presented sequentially, but treated simultaneously as they occur.

\section{The Social Organization of Counselling Work}

Mari and Charlotte are both in their 30s, and have worked as counsellors in vocational rehabilitation programmes for four and nine years, respectively. Mari has a social sciences background and Charlotte is a psychiatric nurse. Despite different programmes and names, the client-group Mari and Charlotte assists, their job requirements and the institutional regulations are quite similar. 
Although they have a standard description of their work on paper, both women describe considerable variation in their day-to-day practice. 'There is no typical vocational rehabilitation process and no typical day at work here', Mari replies when I ask her to describe her work. Mari's very first sentence in our first talk opens up the problematic of how the counsellors' experience of this variety in their work actually plays out. This problematic gives me a starting point from where I can ask questions, follow clues and investigate how it is it that she experiences her job in that particular way. Mari continues:

Our clients do not fit in many places, that's why NAV sent them here. Most of them have very complex problems, and my job is to map out their needs. Based on this mapping process, we make a suitable goal for the Individual Plan. My job is to ask the right questions so that the clients can discover their own resources. Only then, can the clients 'own' their process and feel motivated for working toward their goal. But this sounds easier than what it really is. In each process, I have to cooperate with the client's caseworker at NAV, the general practitioner (GP), often a psychologist, and several different employers. All of them have their own visions about what is best for the clients. I often also support the clients with problems related to, for example, family members, housing, economic problems or drug abuse.

My informants possess expert knowledge within the field of vocational rehabilitation. Their counselling work can be analysed as discursive practices, meaning that their work knowledge expresses particular ruling discourses about how to do vocational rehabilitation. In the quote from the interview with Mari, her professional goal of empowering her clients appears as one such primary and immediate institutional discourse. The work of empowering starts with Mari acquainting herself with her clients' life situation, resources and wishes. Mari is obviously concerned with the broader social and economic needs of the clients, and sees vocational rehabilitation as a process of comprehensive change where employment is only one aspect of change. Her own role is that of the coordinator, pulling the strings and speaking on behalf of the clients.

Due to the complex character of her clients' barriers to employment, Mari's 'empowering work' calls for a holistic and inter-professional approach. The discourse of empowerment is closely connected to another dominant institutional discourse in vocational rehabilitation, which I shall refer to as 'the discourse of inter-professional collaboration'. Each individual process requires the counsellor to engage with a 
constellation of other professionals who represent different fields of work knowledge, professional expertise, interests and ideologies. Furthermore, their roles in the vocational rehabilitation processes differ in terms of commitments and obligations. Thus, as Charlotte states: 'It can be challenging to get the network of helpers around the client to "pull in the same direction."' Mari even compares her coordinating role in the inter-professional collaboration with horse trading:
NAV holds us accountable for the lists of clients in our programmes: How many got employed? How long did the process take? How many are going to apply for disability benefits? We call NAV and ask for more time by stressing this and that. Then we have the GPs and the psychologists with their strong opinions about work capability and possibilities. We must listen to them; they are the health experts. The employers have their own interests of course. We negotiate with them about durations of work placements, potential hiring, wage subsidy questions, etc. We say: 'But you said he worked all right in the checkout counter. Why can't you hire him? What are you unsure about? We can get you a wage subsidy'. It is horse trading all the way. And then, the most important thing of course, is what the clients themselves want.

The counsellors point to different ways of thinking about the clients' work capability as a main challenge in inter-professional collaborations. Counselling work usually builds on reports and advice from the client's health-care providers. Most clients have confidence in their health-care providers, and the counsellors see it as crucial that health-care providers encourage the clients to work and continuously discuss the vocational rehabilitation process in consultations. Even though most of these collaborations work very well, both counsellors experience some health-care providers as 'too focused on the clients' health barriers', making vocational rehabilitation processes a 'one step forward, two steps back process'. They both claim that two people with the same diagnosis and the same work barriers can end up with opposite outcomes of vocational rehabilitation processes, depending on their health-care providers' involvement and encouragement in the process.

The client's caseworker at NAV is another central collaborator for the counsellors. Mari and Charlotte frequently experience a discrepancy between their own understanding of a client's work capability and that of the caseworker. Charlotte asserts that caseworkers often enroll people in vocational rehabilitation programmes just because they express a 'desire to work'. This compounding of 'work capability' and 'desire to work' have resulted in Charlotte having to terminate innumerable processes over the years, because her clients have serious, chronic health problems. According to 
Charlotte, Norwegian authorities have gone too far in embracing the 'naïve idea' that 'everybody can work'. Even though she strongly supports the idea that people with health problems must be given the opportunity to work, she claims that the caseworkers at NAV sometimes, in their eagerness to get people off benefits and into paid work, downplay the seriousness of severe health problems. Similarly, Mari calls NAV's ambitions 'hopelessly naïve'.

As the purchaser and administrator of ALMP programmes in Norway, NAV's regulations and underlying ideologies, for example the idea that 'everyone can work', set the premise for the counsellors' work. Following Newman (2007), dominant discourses within welfare states are not necessarily in alignment. That NAV's control of ALMP programmes are at odds with their own belief in 'employment for all' illustrates this point. NAV strictly regulates the time allotted to individual vocational rehabilitation processes, but the actual time needed to prepare clients (often with considerable health problems) for employment is much greater. Tensions like this are part of the counsellors' daily work, and help explain Mari's comparison between counselling work and horse trading. Adding to the problem, the institutional discourse of NAV sometimes appear to overrule the discourse of empowerment and inter-professional collaboration. This is especially evident in the counsellors' accounts of new practices and demands related to NPM strategies and the public procurement of ALMP programmes.

Until recently, both Mari and Charlotte were permitted to work relatively independently and discretionarily, and to plan their workdays from what they understood as beneficial for each client. However, the outcome of the public procurement of ALMP programmes has led to a new organizational structure and new requirements in the programme Charlotte works in. In the following quote, she describes these changes:

The way I have been working all these years has worked out very well. I have helped so many people to get a job. But in this new programme, I'm always in a hurry. Within the first month, all clients are supposed to be in an external work placement and work $50 \%$. Remember, some of these people are very sick, have never worked and have been isolated for years. It's very hard to find an appropriate place for them within some weeks and all this rushing turns out negatively not only for the clients, but for the employer and for society. If we don't comply with these new requirements, we have to report to NAV and explain why this is so. Besides, I now spend much time on reporting, recording and systematizing, and less time on talking with clients and consulting health-care providers. 
Strict timeframes for when clients are supposed to be in work placements in the ordinary labour market make Charlotte feel like she has to hurriedly place people in more or less random work placements. It gives her a 'bad gut feeling' to risk disempowering experiences for her clients and for the employers. Besides, she now has to report the content of all her meetings with clients to ensure that she does not spend time with them talking about subjects not directly related to 'getting a job'. Charlotte finds it difficult to think strategically and effectively in her work with the clients while providing the same comprehensive work with each individual. The increasing use of performance measurements represents a breach with her habitual way of doing vocational rehabilitation.

Even though Mari's programme has not undergone the same changes as Charlotte's, Mari also describes an increasing focus on standardized practices and a narrower focus on work-related activities that often interfere with the client's needs and expectations, as well as her own habitual work practices. This shift is especially visible during team meetings in her workplace:

Before, we used to discuss individual clients' processes, how the collaboration with 'health' was carried out, what we considered the best opportunities for each client, as well as giving each other useful advice. We were a team, achieving things together, not like now, when each of us is measured individually. Nowadays, performance measurements are the main topic in every meeting on each level. The leaders are stressed out and some of my colleagues have become so strategic that they don't want to work with the heaviest clients any longer. In fact, during meetings I make my mark as someone who doesn't care about these numbers, although I have to care about them somewhere deep inside. It is a big problem that the only way of measuring our work is through the clients' labour market entry. No one measures the good and caring work we do with those who don't get into work. It is quantity over quality.

As pointed out by Brodkin (2013, p. 26), performance measurement creates incentives to pay attention to what is measured and to be less attentive to what is not measured. In the case of vocational rehabilitation, the counsellors' work with improving their clients' life situation is not countable, while the numbers of 'checks' for 'labour market entry' are countable.

The counsellors talk of more reporting, counting and monitoring work to follow up the standardized timelines and targets set by the programme, which seems to interfere both with NAV's employability-enhancing approach and with the practices of 
empowerment and inter-professional collaboration. Whereas the latter discourses are taken for granted and deeply integrated into my informants' practices and understandings of vocational rehabilitation, the 'discourse of accountability' is not. As Charlotte states: 'The changes don't come from inside the field of vocational rehabilitation but from the outside, from someone who forgets that we work with vulnerable people and who believes we can conjure up workplaces.' Mari distances herself from what she sees as externally set measures when she makes herself stand out at meetings by actively not caring about numbers. Mari does not perceive (or does not want to perceive) these measures as her own.

According to Charlotte, she still delivers quality service despite 'new truths in the field'. Nevertheless, the counsellors' accounts of the last-years changes toward increased monitoring, measurements and competition in vocational rehabilitation reveal changes in how their work is done. Charlotte rushes people into work placements that might not be great fits, and has less time to talk to her clients and her collaborators. Mari feels like she always has to defend her use of time, and she is worried about her new and inexperienced colleagues who are 'trained within the performance-oriented counselling role from the start'. Because she is deeply frustrated with the developments within the field, she has decided to quit her job.

\section{How Institutional Ethnography Can Contribute to Research on Vocational Rehabilitation}

As I have argued throughout this article, understanding the complexities of street-level practices requires an account of the extended relations in which they are embedded. The analysis put forward here makes visible the counsellors' experiences of disjuncture between their caring and empowering commitments toward their clients, and a ruling discourse embracing accounting practices. Juggling between different attitudes to the clients' employability and administrative demands can be understood as expressions of the multiple extended relations at play in counselling work. Their work requires Mari and Charlotte to play many roles (bureaucratic servant, recipient of medical expertise, horse trader, caretaker of 'client needs' and 'job specialist' negotiating with employers), all of which can be at odds with one another (e.g. what the client wants vs. what the employer wants, or what the doctor concludes). Equally important, however, the analysis demonstrates that experienced counsellors like Mari 
and Charlotte can handle this 'disjunctive space' (Rankin \& Campbell 2006, p. 180) in different, even oppositional ways. They use their competence and skills to negotiate with, and perhaps even soften, administrative demands. This indicates, at least for the present, that the counsellors are still able to use discretion in working with their clients and collaborators, which is so important in the field of vocational rehabilitation.

As previously argued, empirical studies on implementation often have a weak point in their transition from individual experience and activities at the micro (subject) level to a conceptualization of social structures and discourses at the macro (system) level. Even though much of this literature claims to take, for example, frontline workers' viewpoints, the frontline workers tend to disappear during the analysis. Instead of locating the informants as active subjects at the forefront throughout the analysis, the informants' activities are replaced with concepts and abstractions related to the system level. How these levels are interrelated remains unclear.

In IE, the social is always considered to be produced by people's practices. Discourses and other dominant abstractions and concepts within vocational rehabilitation do not exist in themselves, and cannot be treated as if they were agents or without reference to actual practices. This 'method of inquiry' (Smith, 2005) implies a view on relations of ruling as something that happens through us instead of to us. Accordingly, I studied the ruling discourses through Mari and Charlotte's practices, and paid particular attention to prevailing terms and ideas that could display evidence of dominance (Townsend, 1996, p. 190). IE analyses have a potential to clarify the reasons for people's choices and actions because they make explicit and transparent the social processes behind people's practices. In research on activation and vocational rehabilitation, in which the interaction processes are institutionally and ideologically governed, while at the same time shaped by relatively autonomous actors, this transparency is particularly important.

\section{Conclusion: What Future IE Studies of Vocational Rehabilitation May Look Like}

This article has examined how IE can inform empirical studies of vocational rehabilitation processes. Due to my focus on the benefits of IE, and my main ambition 
to inspire future research within the field to apply IE, I have left out the findings and conclusions from my own larger study, as well as a more critical discussion of IE.

The field's interdisciplinary and inter-organizational character makes vocational rehabilitation complex, somewhat fragmented and hard to define and delimit. This complexity provides many opportunities for discovering problematics from various local standpoints. By studying vocational rehabilitation processes from the counsellors' standpoints, we can investigate their relationships with clients, their collaboration with health-care providers, how they are influenced in their practices by organizational and bureaucratic guidelines, or how they recruit and cooperate with employers. Another possibility is to take the employers' standpoints and examine how processes of inclusion take place in various workplaces. Attention to employers' needs, viewpoints and roles in vocational rehabilitation could provide us with valuable information about how employers relate to 'the welfare system moving into their arena' (Hernes, 2015, p. 308). The clients' perspectives are another important starting point, as the clients have the most at stake. Consequently, their stories can help us understand vocational rehabilitation processes as embodied experiences of inclusion and exclusion. Even so, regardless of whichever standpoint we choose as our primary resource, an institutional ethnographic approach will examine vocational rehabilitation as an interactional process.

\section{End note}

1. In this context, work does not necessarily mean paid work or what we generally think of as work. Rather, Smith defines work very broadly, as anything that takes time, effort and intent (2005, p. 229). 


\section{References}

Aakvaag, G. C. (2008). Moderne sosiologisk teori. Oslo: Abstrakt forlag.

Andreassen, T. A., \& Fossestøl, K. (2014). Utfordrende inkluderingspolitikk:

Samstyring for omforming av institusjonell logikk i arbeidslivet, helsetjenesten og NAV. Tidsskrift for samfunnsforskning, 55(2), 173-202.

Anker, J., \& Halvorsen, R. (2007). Claiming participation rights: Social mobilization and citizenship in Denmark and Norway. In B. Hvinden \& H. Johansson (Eds.), Citizenship in Nordic Welfare States: Dynamics of choice, duties and participation in a changing Europe (pp. 97-111). Bodmin: Routledge.

Bisaillon, L. (2012). An Analytic Glossary to Social Inquiry Using Institutional and Political Activist Ethnography. International Journal of Qualitative Methods, 11(5), 607-627.

Blumer, H. (1969). Symbolic Interactionism. Perspective and Method. Berkeley: University of California Press.

Bonoli, G. (2014). Employers' attitudes towards long-term unemployed people and the role of activation in Switzerland. International Journal of Social Welfare, 23(4), 421-430.

Brodkin, E. Z. (2013). Street-Level Organizations and the Welfare State. In E. Z. Brodkin \& G. Marston (Eds.), Work and the Welfare State Street-Level Organizations and Workfare Politics (pp. 17-34). Washington: Georgetown University Press. ${ }^{\mathrm{i}}$

Brodkin, E. Z., \& Marston, G. (2013). Work and the Welfare State: Street-Level Organizations and Workfare Politics. Washington: Georgetown University Press.

Campbell, M., \& Gregor, F. (2008). Mapping Social Relations: A primer in Doing Institutional Ethnography. Walnut Creek, CA: Altamira Press.

DeVault, M., \& McCoy, L. (2006). Institutional Ethnography: Using Interviews to Investigate Ruling Relations. In D. Smith (Ed.), Institutional Ethnography as Practice (pp. 15-44). Oxford: Rowman \& Littlefield.

Deveau, J. L. (2008). Examining the Institutional Ethnographer's Toolkit. The Journal of the Society for the Socialist Studies, 4(2), 1-20.

Dubois, V. (2010). The Bureaucrat and the Poor. Encounters in French Welfare Offices. Surrey: Ashgate. 
Forte, J. A. (2004). Symbolic Interactionism and Social Work: A forgotten Legacy, Part 1. Families in Societies: The Journal of Contemporary Social Services, 85(3), 391-400.

Goffman, E. (1959). The presentation of self in everyday life. New York: Anchor Books.

Grahame, P. R. (1998). Ethnography, Institutions, and the Problematic of the Everyday World. Human Studies, 21(4), 347-360.

Greve, B. (2014). Welfare and the Welfare State: Present and future. New York: Routledge.

Halvorsen, R., \& Hvinden, B. (2011). Andre lands modeller for å fremme sysselsetting blant personer med nedsatt funksjonsevne. NOVA report 14/2011.

Heggebø, K. (2016). Hiring, employment, and health in Scandinavia: The Danish 'flexicurity' model in comparative perspective. European Societies, 18(5), 460-486.

Helgøy, I. (1998). Den institusjonsbaserte attøringen i Skandinavia: Diagnostisering, arbeidsformidling og samtaleterapi. (PhD Thesis), Bergen: Universitetet i Bergen.

Hernes, T. (2015). Arbeidsinkludering: Noen historiske spenninger og aktuelle utfordringer. In K. Frøyland \& Ø. Spjelkavik (Eds.), Inkluderingskompetanse: Ordinært arbeid som mål og middel (pp. 306-325). Oslo: Gyldendal Akademisk.

Horner, B. (1979). Symbolic interactionism and social assessment. Journal of Sociology and Social Welfare, 6(1), 19-33.

Hupe, P., \& Hill, M. (2007). Street-level Bureaucracy and Public Accountability. Public Administration, 85(2), 279-299.

Ingold, J., \& Stuart, M. (2014). The Demand-Side of Active Labour Market Policies: A Regional Study of Employer Engagement in the Work Programme. Journal of Social Policy, 44(03), 443-462.

Järvinen, M., \& Mik-Meyer, N. (2003). At skabe en klient: Institusjonelle identiteter i socialt arbejde. Copenhagen: Hans Reitzels Forlag.

Kasin, M. \& Sannes, B. (2012). Fra vernet bedrift i et vernet marked, til tiltaksbedrift $i$ et konkurranseutsatt marked: Framtidige tjenesteleveranser i et uforutsigbart marked. (Master Thesis), Oslo: Høyskolen i Oslo og Akershus. 
Lipsky, M. (1980). Street-Level bureaucracy: Dilemmas of the individual in public services. New York: Russell Sage.

Lundberg, K. G. (2012). Uforutsigbare relasjoner: Brukererfaringer, Nav-reformen og levd liv. (PhD Thesis), Bergen: Universitetet i Bergen.

Martin, C. J. (2004). Reinventing Welfare Regimes: Employers and the Implementation of Active Social Policy. World Politics, 57(1), 39-69.

Meyers, M. K., \& Vorsanger, S. (2003). Street-Level Bureaucrats and the Implementation of Public Policy. In G. Peters \& J. Pierre (Eds.), Handbook of Public Administration (pp. 245-256). London: SAGE.

Mäkitalo, Å. (2006). Effort on display: Unemployment and the interactional management of moral accountability. Symbolic interaction, 29(4), 531-556.

Newman, J. (2007). The 'double dynamics' of activation: Institutions, citizens and the remaking of welfare governance. International Journal of Sociology and Social Policy, 27(9/10), 364-375.

Olsen, T. (2009). Versjoner av arbeid: Dagaktivitet og arbeid etter avviklingen av institusjonsomsorgen. (PhD Thesis), Uppsala Universitet.

PROBA (2016). Evaluering av offentlig anskaffelse: Nytt avklarings- og oppfølgingstiltak. Delrapport 1.

Rankin, J. M., \& Campbell M. L. (2006). Managing to Nurse: Inside Canada's Health Care Reform. Toronto: University of Toronto Press.

Smith, D. E. (2005). Institutional Ethnography: A Sociology for People. Oxford: AltaMira Press.

Smith, G. (1990). Political Activist as Ethnographer. Social Problems, 37(4), 629648.

Thorén, K. (2008). Activation Policy in Action: A Street-Level Study of Social Assistance in the Swedish Welfare State. (PhD Thesis), Växjö University Press.

Townsend, E. (1996). Institutional Ethnography: A Method for Showing How the Context Shapes Practice. Occupational Therapy Journal of Research, 16(3), 179-199.

Van Berkel, R. (2007). Individualised activation services in the EU. In R. Van Berkel \& B. Valkenburg (Eds.), Making it Personal: Individualising Activation Services in the EU. (pp. 245-264). Bristol: The Policy Press. 
Van Berkel, R., \& Valkenburg, B. (2007). The individualisation of activation services in context. In R. Van Berkel \& B. Valkenburg (Eds.), Making it Personal: Individualising Activation Services in the EU. (pp. 3-21). Bristol: The Policy Press.

Van Berkel, R., \& Knies, E. (2016). Performance Management, Caseloads and the Frontline Provision of Social Services. Social Policy \& Administration, 50(1), 59-78.

Van der Aa, P. \& Van Berkel, R. (2014). Innovating job activation by involving employers. International Social Security Review, 67(2), 11-27.

Walby, K. (2007). On the Social Relations of Research: A Critical Assessment of Institutional Ethnography. Qualitative Inquiry, 13(7), 1008-1030.

Widerberg, K. (2015). I hjertet av velferdsstaten: En invitasjon til institusjonell etnografi. Oslo: Cappelen Damm akademisk.

White Paper no. 9 (2006-2007). Arbeid, velferd og inkludering. Oslo: Arbeids- og sosialdepartementet. 